\title{
Acute and Subchronic Toxicity Profile of Euphorbia pulcherrima Methanol Extract on Wistar Albino Rats
}

\author{
H. B. Sharif, ${ }^{1}$ M. D. Mukhtar, ${ }^{2}$ Y. Mustapha, ${ }^{2}$ Gabi Baba, ${ }^{1}$ and A. O. Lawal ${ }^{1}$ \\ ${ }^{1}$ Department of Applied Science, College of Science and Technology, Kaduna Polytechnic, PMB 2021, Kaduna, Nigeria \\ ${ }^{2}$ Department of Microbiology, Bayero University, Kano, Kano, Nigeria
}

Correspondence should be addressed to H. B. Sharif; sharifgoshi@yahoo.com

Received 30 August 2014; Revised 22 December 2014; Accepted 7 January 2015

Academic Editor: Maria Cristina Bonferoni

Copyright (C) 2015 H. B. Sharif et al. This is an open access article distributed under the Creative Commons Attribution License, which permits unrestricted use, distribution, and reproduction in any medium, provided the original work is properly cited.

\begin{abstract}
This work was designed to evaluate the acute and subchronic toxicity of E. pulcherrima methanol extract. Mean lethal dose $\left(\mathrm{LD}_{50}\right)$ and subchronic toxicity were determined using Lorke's method to assess the effect of the extract on kidney and liver functions along histopathology assessment of the liver and kidney, respectively. The $\mathrm{LD}_{50}$ determined was $3807.89 \mathrm{mg} / \mathrm{kg}$ both orally and intraperitoneally. The kidney function parameters indicated elevation of the serum urea above the normal value in both control and the group treated with $10 \mathrm{mg} / \mathrm{kg}$ of the extract with mean values of $7.92 \pm 1.19$ and $7.86 \pm 1.14 \mathrm{mMol} / \mathrm{L}$, respectively. The creatinine and electrolytes were within the normal values. The results of ALAT, ASAT, ALP, T protein albumin, and bilirubin in all cases were within the normal values. Kidney, liver function parameters, and relative organ weight were statistically insignificant across all groups. This shows that various concentrations of E. pulcherrima extract did not influence negatively the liver and kidney function parameters. Further studies are required to rule out the observed mild hepatic histological changes among a few members of the groups treated with 100 and $1000 \mathrm{mg} / \mathrm{kg} / \mathrm{day}$ and any possible hepatoprotective and nephron-protective potential the extract may possess.
\end{abstract}

\section{Introduction}

The usage of medicinal plants to treat ailments in traditional medicine is not always a reliable guarantee in terms of safety since it is difficult for the traditional practitioners to detect or monitor delayed effects, rare adverse effects, and adverse effects such as mutagenicity, arising from long-term administration. There has been increasing interest in the use of medicinal herbs for meeting the goal of primary health care delivery worldwide [1]. Accordingly, investigations into toxicity of medicinal plants have been carried out [2-4] and are ongoing as verse group of medicinal plants need to be explored studied.

Plants are one of the most important sources of medicine [5]. Plant derived compounds (phytochemicals) have been attracting much interests as natural alternatives to synthetic compounds. Extracts of plants are used for the treatment of various diseases which forms the basis for all traditional systems of medicine [5].
The treatment and control of diseases by the use of available medicinal plants in a locality will continue to play significant roles in medical health care implementation in the developing countries [6].

In recent years, considerable interest has been evidenced by the medicinal and pharmacological professionals, regarding the use of indigenous drugs in the treatment of diseases [7]. The toxic effects produced by the administration of drugs as derivatives of these plants are much more a serious problem than that of the disease itself [8].

Euphorbia pulcherrima is a popular Christmas plant grown for its red leafy bracts. It is a nontoxic plant although some species of the family Euphorbiaceae that produce latex are toxic [9]. This flowering plant indigenous to Mexico and the Central America has large green and red leaves. It was reportedly introduced to the United States in 1829 by J. R. Poinsett, the American Ambassador to Mexico at that time. In the wild form, it is a large, woody shrub commonly growing $10 \mathrm{ft}$ high. Indoors, it is typically much smaller with denser 
leaves. It is commonly used as a Christmas decoration and this makes its majority of exposures in the months of November, December, January, and February.

It has various medicinal properties which include its use in the treatment of gonorrhea, respiratory tract infection, malaria, eczema, asthma, and warts cure [9]. Poinsettia (Euphorbia pulcherrima) has been used as a hair removal cream in Mexico and Guatemala. The latex has been used as a remedy for toothache and anti-vomiting agent. Poultices of leaves have been applied to treat aches and pains [9]. The whole plant and its sap (latex) are used to make medicines despite the safety concern. People take poinsettia to treat fever and stimulate breast milk production, though it is said to cause abortion when taken by pregnant woman. In a related development it is said that the ethanol extract and water free extract of the plantleaves contain some wound healing properties [9].

Euphorbia pulcherrima in recent years is engulfed with a lot of debate over its toxicity. In the past couple of years some commercial sources of Euphorbia pulcherrima have stated emphatically that this is a myth and that the plant is harmless [9].

The public and some health professionals thought that it is a much maligned plant and is extremely toxic to humans. Studies have accounted for 22,793 cases of poison by control centers but surprisingly there were no fatalities among all poinsettia exposures in which $98.9 \%$ were accidental in nature and 93.3\% were exposures involving children [10].

The majority of exposed patients (96.1\%) did not require treatment in health care facility and $92.4 \%$ did not develop any toxicity related to their exposure to the poinsettia. Most patients did not require any type of therapy and were treated without been referred to a health care facility [10].

Despite that, toxicity is documented in most of the genus Euphorbia, but it is based on individual sensitivity. Other sources including Southern and Eastern Africa clearly state that the latex is highly irritative. However, in the Netherlands, Indies, and Indonesia, the bark, leaf, and root are regarded as being markedly toxic and in South China the plant is used as a fish poison [11].

Few studies have reported the allergic potential of Euphorbia pulcherrima like rhinitis and asthma induced by Euphorbia pulcherrima, but patients were able to tolerate with few reported cases of contact dermatitis due to latex of Euphorbia pulcherrima. The latex was found to have a depilatory effect as it contains from $5 \%$ to $15 \%$ caoutchouc and resins [12]. This has to do with the removal of unwanted hair from the body due to its toxicity [12].

It is thus very clear that the safety of Euphorbia pulcherrima is surrounded by controversies. This coupled with the fact that it is used in Hausaland ethno-pharmacopeia to treat gastro enteritis related ailments in Nigeria [12]. This informs the need to investigate the acute toxicity, using lethal dose $\left(\mathrm{LD}_{50}\right)$ as the index, and the subacute toxicity with special consideration for its effect with respect to damage on organs such as the kidney and liver. Therefore, this work is designed to determine the lethal dose $\left(\mathrm{LD}_{50}\right)$, subchronic toxicity, and the immunostimulatory effect of E. pulcherrima extract on wistar albino rats (experimental models) using the methods described by Lorke [13], [14], and [15], respectively.

\section{Materials and Methods}

The whole E. pulcherrima plant was freshly collected in dry season between the months of November and December 2013 and identified by a botanist at the Herbarium unit of Plant Sciences Department, Bayero University, Kano. The voucher number BUKHAN 273 was deposited at the herbarium. The toxicological analysis of the crude methanol extract of the whole E. pulcherrima was carried out at the Department of Pharmacology, the Faculty of Pharmaceutical Sciences, Ahmadu Bello University Zaria, Kaduna State, Nigeria.

2.1. Preparation of Plant Materials. The entire whole plant samples comprised of the red and green leaves, roots, stems, and flowers were washed with distilled water, cut into small pieces, and shade dried at room temperature $\left(25^{\circ} \mathrm{C}\right)$ for two weeks. The red leaves occurred as 1-2 rows of bracts surrounding the cyathium inflorescence of the flower, while the green leaves dominated the whole plant. Five hundred grams of shade dried whole plant materials was pulverized into powder using sterile pestle and mortar and extracted exhaustively using Soxhlet apparatus with 2.5 litres of methanol. The extract was concentrated by rotary evaporator under reduced pressure and stored under dry state until it is required for use. The percentage yield of the crude extract was calculated using the following formula:

$$
\begin{aligned}
\text { Percentage yield }= & \frac{\text { mass of extract }}{\text { total mass of sample extracted }} \\
& \times 100 \% .
\end{aligned}
$$

2.2. Animals. Male adult Wistar rats $(180-240 \mathrm{~g})$ were used for the acute toxicity studies and rats weighing between 200 and $250 \mathrm{~g}$ were used for the subchronic toxicity profiling. The animals were obtained from National Institute of Trypanosomiasis and Onchocerciasis Research, Kaduna, Nigeria. They were fed ad libitum with standard feed and had free access to water. They were also maintained under standard conditions of humidity, temperature, and $12 \mathrm{~h} \mathrm{light/darkness} \mathrm{cycle.} \mathrm{The}$ animals were allowed to acclimatize for two weeks before the commencement of the study. A standard protocol was followed in accordance with the Good Laboratory Practice (GLP). The "principles of laboratory animal care" were also observed in this study.

2.3. Chemicals. Kits for glutamate oxaloacetate transaminase (GOT and AST), glutamate pyruvate transaminase (GPT and ALT), alkaline phosphatase (ALP), total proteins, albumin, total bilirubin, urea, and creatinine were obtained from Human Gesellschaft für Biochemica and Diagnostica MBH, Germany, and used for the biochemical studies.

2.4. Acute Toxicity Studies. The acute toxicity $\left(\mathrm{LD}_{50}\right)$ was estimated both orally and intraperitoneally in rats $(n=13)$ in 
each case following Lorke's method [13]. Dose levels of 10, 100, and $1000 \mathrm{mg} / \mathrm{kg}$ were used for the first phase. The number of deaths in each group within 24 hours was recorded. In the second phase which was deduced from the first phase, four rats were grouped into four groups of one rat each and they were treated with doses of $1200 \mathrm{mg} / \mathrm{kg}, 1600 \mathrm{mg} / \mathrm{kg}$, $2900 \mathrm{mg} / \mathrm{kg}$, and $5000 \mathrm{mg} / \mathrm{kg}$ orally and intraperitoneally. They were also observed for 24 hours as in the first phase, and final $\mathrm{LD}_{50}$ value was determined from Lorke's formula as follows:

$$
\mathrm{LD}_{50}=\sqrt{a \times b},
$$

where $a$ is the highest dose at which no death occurred in the second phase and $b$ is the least dosage at which death occurred in the 2nd phase [16]. The extract was classified using the $\mathrm{LD}_{50}$.

2.5. Subchronic Toxicity Studies. Twenty rats were selected by stratified randomization and then divided into four groups of five each. The first group served as control, while the remaining three groups were given 100,100 , and $1000 \mathrm{mg} / \mathrm{kg}$ of extracts orally for 28 days. The first day of dosing was considered as $\mathrm{D}_{0}$, whereas the day of sacrifice was designated as $\mathrm{D}_{28}$.

2.6. Mortality and Clinical Signs. During the four-week dosing period, all the animals were observed on daily basis for likely clinical signs and mortality patterns once before dosing, immediately after dosing, and up to 4 hours after dosing.

2.7. Relative Organ Weight. On day 28 of the dosing period, the animals were starved for $24 \mathrm{hrs}$; on day 29 all the animals were euthanized by exsanguination under chloroform anesthesia. The liver and kidneys were carefully dissected out and weighed in grams (absolute organ weight). The relative organ weight of each animal was then calculated as

\section{Relative Organ Weight}

$$
=\frac{\text { Absolute organ weight }(\mathrm{g})}{\text { Body weight of rat on sacrifice day }(\mathrm{g})} \times 100 \text {. }
$$

2.8. Gross Pathology and Microscopic Examination. The liver and the two kidneys for each rat were fixed and preserved in $10 \%$ formaldehyde before subjection to tissue processing procedures for the preparation of permanent mount of each tissue as described by Sofowora [14]. The tissues were dehydrated through various grades of alcohol comprised of $30,50,70$, and $95 \%$ with a final bath in $100 \%$ alcohol (twice) to ensure total elimination of moisture. Clearing was performed in toluene in order to raise its refractive index to that of glass (1.5) to enable transparency of the cellular inclusions. The processes of infiltration and embedding were performed using liquid paraffin and molten paraffin wax using L-shaped mould, respectively. Sections were made using Rotary Microtome and the Hot plate method was used for mounting specimens onto slides. Staining of tissues was performed using iron hematoxylin and eosin stains. Canada balsam was used in mounting the tissues [17]. Slides were viewed under the $\times 40$ objective of the light microscope and photographed using the digital eye piece camera (Model 582, Oplenic optronic Kina) to capture tissues images.

2.9. Preparation of Sera Samples. On day 28 of the dosing period, the animals were starved for $24 \mathrm{hrs}$, and on day 29 all the animals were exsanguinated under chloroform anesthesia and blood samples were drawn from the heart of each sacrificed animal. The samples were collected in sterilized plain plastic test tubes and allowed to stand for 3 hours to ensure complete clotting. The clotted blood samples were then centrifuged at $3000 \mathrm{rpm}$ for 10 minutes and clear serum samples were aspirated off and stored and were frozen for the biochemical test.

2.10. Serum Biochemistry. The parameters were determined colorimetrically by employing the standard ready-to-use kits and methods of Human [18] for glutamate oxaloacetate transaminase (GOT, AST), glutamate pyruvate transaminase (GPT, ALT), alkaline phosphatase (ALP), total proteins, albumin, total bilirubin, serum urea, creatinine, and electrolytes (sodium, potassium, bicarbonate, and chloride). The manufacturer's instructions for each biochemical parameter were strictly adhered to in the course of the investigations.

\subsection{Immunostimulatory Effect of E. pulcherrima Whole} Plant Methanol Extract on Total Leucocyte Count (TLC) and Differential Leucocyte Count (DLC). Total leucocytes count measures the cellular immunity in which phagocytic cells WBC were found, while the differential leucocytes count (DLC) measures the various cells found in the WBC because each performs different function. The increase in both TLC and DLC is an indication of immunostimulatory effect due to direct effect on the bone marrow or blast transformation of the WBC [16]. The blood samples collected were used to investigate the packed cell volume (PCV), haemoglobin $(\mathrm{Hb})$, total protein, white blood cell (WBC), neutrophils, lymphocytes, monocytes, basophils, eosinophils, and bands which were determined by laboratory procedures described by Sofowora [14]. The method of Chidume et al. [19] was adopted for the determination of the total leucocytes count (TLC) and differential leucocytes count (DLC). Twelve mice were grouped into four and three in each group. The first group was administered with distilled water that served as control. The second, third, and fourth groups were administered with the extract at concentration doses of 25,50 , and $100 \mathrm{mg} / \mathrm{kg}$ intraperitoneally, respectively, on the 1st, 5th, and 9th days. On the 10th day, blood samples were taken from all the groups for TLC and DLC determination. The blood samples were collected by applying pressure on their tails and then cutting off the tip of each tail. White cell diluting pipette (capillary tube) was used to collect blood directly from the tail of the rats for TLC. The TLC was done by making 1:20 dilution of the samples with white cell diluting fluid and counting with the aid of improved Neubauer counting chamber under the microscope at $\times 10$ magnification. The DLC was determined by making a thin film of the blood samples on microscopic 
TABle 1: Acute toxicity tests of E. pulcherrima extract.

\begin{tabular}{|c|c|c|}
\hline \multirow[b]{2}{*}{ Doses $(\mathrm{mg} / \mathrm{kg})$} & \multicolumn{2}{|c|}{ Survival rate (phase 1 ) } \\
\hline & $\begin{array}{c}\text { Oral } \\
\text { Death/survive }\end{array}$ & $\begin{array}{l}\text { Intraperitoneal } \\
\text { Death/survive }\end{array}$ \\
\hline 10 & $0 / 3$ & $0 / 3$ \\
\hline 100 & $0 / 3$ & $0 / 3$ \\
\hline 1000 & $0 / 3$ & $0 / 3$ \\
\hline Doses $(\mathrm{mg} / \mathrm{kg})$ & \multicolumn{2}{|c|}{ Survival rate (phase 11) } \\
\hline 1200 & $0 / 1$ & $0 / 1$ \\
\hline 1600 & $0 / 1$ & $0 / 1$ \\
\hline 2900 & $0 / 1$ & $0 / 1$ \\
\hline 5000 & $1 / 1$ & $1 / 1$ \\
\hline
\end{tabular}

$\mathrm{LD}_{50}$ (oral) and (intraperitoneal) $=3807.89 \mathrm{mg} / \mathrm{kg}$.

slides and staining with the Leishman stain. The films were air dried at ambient temperature and examined microscopically under oil immersion using $\times 100$ magnification.

2.12. Statistical Analysis. The results were statistically expressed as means standard error of the mean (SEM). The data was further analyzed using Latin square Design three-way analysis of variance (ANOVA) using the IBM SPSS version 20.0 for the test of significant difference at $95 \%$ level $(P<0.05)$. The Turkey hierarchy significant difference test was carried out for the purpose of ranking the order of the effects of treatments applied.

\section{Results}

3.1. Yield, Colour, and Toxicity of E. pulcherrima. The percentage yield and the physical characteristics of the methanol extract of E. pulcherrima obtained by Soxhlet extraction were $5.14 \%$ with dark green coloured appearance.

The results of the acute toxicity tests of E. pulcherrima extract are shown in Table 1.

The result of the acute toxicity test revealed the $\mathrm{LD}_{50}$ to be $3807.89 \mathrm{mg} / \mathrm{kg}$ through both oral and intraperitoneal route of administration.

\subsection{Effect of the E. pulcherrima Extract on the Serum Urea,} Creatinine, and Electrolytes (Kidney Function Parameters) of the Rats. The result of the kidney function parameters test indicated elevation of the serum urea level above the normal reference value in both the control group and the group treated with $10 \mathrm{mg} / \mathrm{kg}$ of the extract with mean values $7.92 \pm 1.19$ and $7.86 \pm 1.14 \mathrm{mMol} / \mathrm{L}$ (Table 2). The results of creatinine and the electrolyte $\left(\mathrm{Na}^{+}, \mathrm{K}^{+}, \mathrm{Cl}^{-}\right.$, and $\left.\mathrm{HCO}_{3}{ }^{-}\right)$on the other hand were within the normal reference values and statistically indicated that $P>0.05$, that is, no significant difference within the average values of the electrolytes $\left(\mathrm{Na}^{+}\right.$, $\mathrm{K}^{+}, \mathrm{Cl}^{-}$, and $\mathrm{HCO}_{3}^{-}$) across all groups. In other words, various concentrations of $E$. pulcherrima extracts did not influence any significant changes on the serum electrolytes of the treated animals. However, creatinine and urea mean values showed significant difference $(P<0.05)$ across the

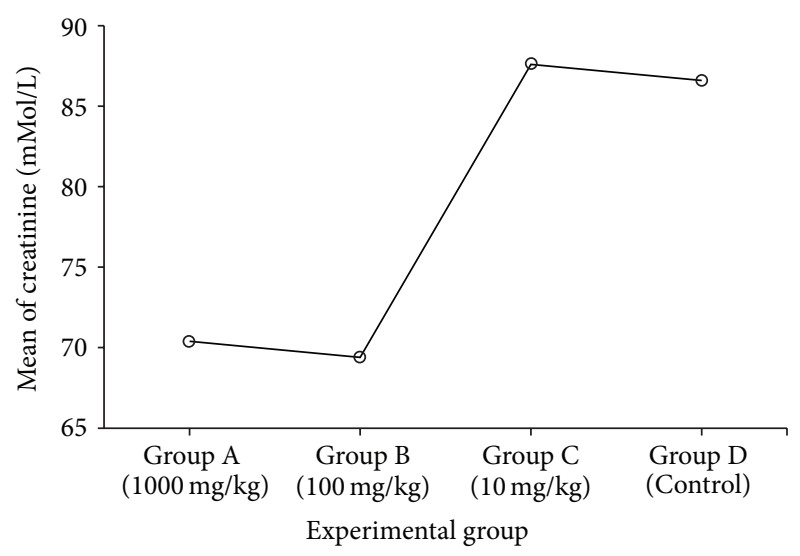

FIgURE 1: Mean plot of creatinine level across the groups' depiction of significant level.

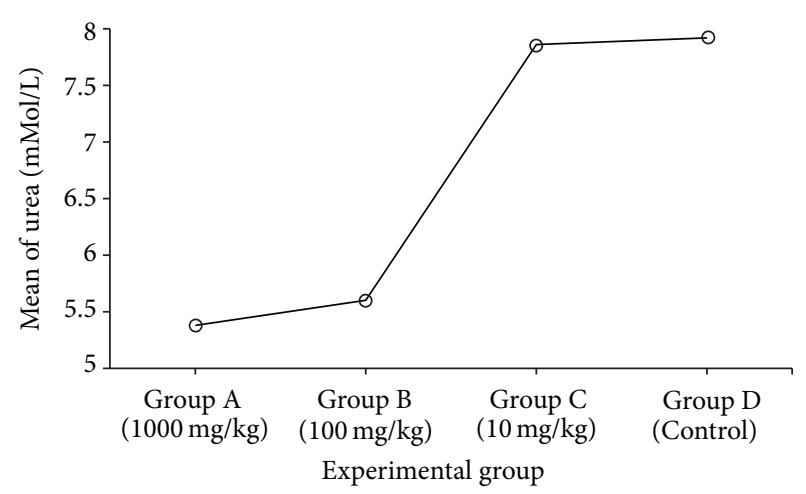

FIGURE 2: Mean plot of urea level across the groups' depiction of significant level.

treated groups and the control group. It was however noted that the mean values of creatinine level across the groups were within the normal reference values.

The significant difference indicated by the serum creatinine and urea level was further examined using the Tukey honest-significant difference (HSD) test to investigate real differences therein across all the groups (Table 3 ).

From the result of the Turkey honest-significant difference (HSD) test in Table 3, in the first homogeneous subset, it can be deduced that groups treated with 1000 and $100 \mathrm{mg} / \mathrm{kg}$ had less creatinine and the group treated with $10 \mathrm{mg} / \mathrm{kg}$ and the control group had more creatinine. This is depicted by the mean plot in Figure 1.

From the result of the Turkey honest-significant difference (HSD) tests in Table 4, the first homogeneous subset indicates that groups treated with 1000 and $100 \mathrm{mg} / \mathrm{kg}$ had less urea and the group treated with $10 \mathrm{mg} / \mathrm{kg}$ and the control group had more urea. This is depicted by the mean plot in Figure 2.

The result of the analysis showed a negative correlation between the concentration of the plant extract and the elevation of the urea and creatinine; that is, when concentration increased, the levels of the parameters decreased (Table 2). 
TABLE 2: Effect of the E. pulcherrima extract on the serum urea, creatinine, and electrolytes level (kidney function parameters) of rats.

\begin{tabular}{|c|c|c|c|c|}
\hline $\begin{array}{l}\text { Kidney parameters } \\
\text { (reference values) }\end{array}$ & $\begin{array}{c}\text { Group A } \\
(1000 \mathrm{mg} / \mathrm{Kg})\end{array}$ & $\begin{array}{c}\text { Group B } \\
(100 \mathrm{mg} / \mathrm{Kg})\end{array}$ & $\begin{array}{c}\text { Group C } \\
(10 \mathrm{mg} / \mathrm{Kg})\end{array}$ & $\begin{array}{l}\text { Group D } \\
\text { (Control) }\end{array}$ \\
\hline $\begin{array}{l}\mathrm{Na}^{+}(\mathrm{Mol} / \mathrm{L}) \\
(135-150)\end{array}$ & $129.8 \pm 0.38$ & $133.8 \pm 2.44$ & $132.6 \pm 1.64$ & $132.8 \pm 2.39$ \\
\hline $\begin{array}{l}\mathrm{K}^{+}(\mathrm{Mol} / \mathrm{L}) \\
(3.4-5.3)\end{array}$ & $3.58 \pm 0.09$ & $3.8 \pm 0.56$ & $3.8 \pm 0.77$ & $3.7 \pm 0.56$ \\
\hline $\begin{array}{l}\mathrm{Cl}^{-}(\mathrm{mMol} / \mathrm{L}) \\
(95-110)\end{array}$ & $85.8 \pm 0.66$ & $93.2 \pm 3.35$ & $91.6 \pm 2.75$ & $91.8 \pm 2.94$ \\
\hline $\begin{array}{l}\mathrm{HCO}_{3}^{-}(\mathrm{Mol} / \mathrm{L}) \\
(24-32)\end{array}$ & $25.8 \pm 0.66$ & $25.8 \pm 1.34$ & $25.6 \pm 1.35$ & $26.6 \pm 1.16$ \\
\hline $\begin{array}{l}\text { Creatinine }(\mathrm{mMol} / \mathrm{L}) \\
(90-126)\end{array}$ & $70.4 \pm 5.57$ & $69.4 \pm 1.75$ & $87.6 \pm 3.81$ & $86.6 \pm 3.0$ \\
\hline $\begin{array}{l}\text { Urea }(\mathrm{mMol} / \mathrm{L}) \\
(2.5-6.5)\end{array}$ & $5.38 \pm 0.58$ & $5.6 \pm 0.95$ & $7.86 \pm 1.14$ & $7.92 \pm 1.19$ \\
\hline
\end{tabular}

Values are expressed as mean \pm SEM for $N=5$. Values are considered significant if $(P<0.05)$.

TABLE 3: Tukey's HSD test for serum creatinine level of rats treated with E. pulcherrima extract.

\begin{tabular}{lccc}
\hline Groups & $N$ & \multicolumn{2}{c}{ Homogeneous subsets } \\
& & 1 & 2 \\
\hline Group B $(100 \mathrm{mg} / \mathrm{Kg})$ & 5 & 69.40 & \\
Group A $(1000 \mathrm{mg} / \mathrm{Kg})$ & 5 & 70.40 & 86.60 \\
Group D (Control) & 5 & & 87.60 \\
Group C (10 mg/Kg) & 5 & &
\end{tabular}

Means for groups in homogeneous subsets are displayed.

TABLE 4: Tukey's HSD test for serum urea level of rats treated with E. pulcherrima extract.

\begin{tabular}{lccc}
\hline Groups & $N$ & \multicolumn{2}{c}{ Homogeneous subsets } \\
& & 1 & 2 \\
\hline Group A $(1000 \mathrm{mg} / \mathrm{Kg})$ & 5 & 5.38 & \\
Group B $(100 \mathrm{mg} / \mathrm{Kg})$ & 5 & 5.60 & 7.86 \\
Group C $(10 \mathrm{mg} / \mathrm{Kg})$ & 5 & & 7.92 \\
Group D (Control) & 5 & & \\
\hline
\end{tabular}

Means for groups in homogeneous subsets are displayed.

These changes cannot be directly linked to the toxicity effect of the extract, since the mean values of the creatinine and urea of the groups treated with higher concentration of the extracts were practically not influenced positively by the extract.

\subsection{Effect of the E. pulcherrima Extract on the Liver Function} Parameters. The descriptive analysis of the results revealed elevation of the liver function parameters such as ALAT, ALP, $\mathrm{T}$ protein albumin, and bilirubin above the normal reference values. However, the ASAT level was within the normal reference values (Table 5). The statistical analysis of ALAT, ASAT, ALP, T protein albumin, and bilirubin in all cases showed that $P>0.05$, that is, no significant difference in the average values of ALAT, ASAT, ALP, T protein, T. bilirubin, C. bilirubin, and albumin across the groups. In other words, various concentrations of E. pulcherrima plant extract do not really influence the level of the liver function parameters tested.

3.4. The Effect of the of E. pulcherrima Extract on the Relative Organ Weight of Liver and Kidney. The result of the relative organ weight (Table 6) indicated statistically that the mean values of both liver and kidney showed $P>0.05$. It is therefore concluded that there is no significant difference in the average relative organ weights of the liver and the kidney of the treated groups and the control group. In other words, various dose concentrations of $E$. pulcherrima plant extract did not really influence the relative organ weight of both liver and kidney.

\subsection{Immunostimulatory Effects of E. pulcherrima Extract on} the Total and Differential Leucocytes Counts. The result of the total and differential leucocytes counts (Table 7) of the control and treated cases showed $P>0.05$. Therefore, there is no significant difference in the average values of the parameters such as PCV, Hb, T Protein, WBC, NEUT, LYMPH, and RBC across all groups. This therefore implies that various dose concentrations of E. pulcherrima extract do not really influence both total and differential leucocytes counts (Table 7).

3.6. Histopathology of Liver of Experimental Model Treated with E. pulcherrima Extracts. The result of the liver histopathology showed that the control group and the group treated with $10 \mathrm{mg} / \mathrm{kg} / \mathrm{day}$ of the extract showed normal histology of liver (Figure 3). Rat treated with $100 \mathrm{mg} / \mathrm{kg} / \mathrm{day}$ showed mild portal lymphocytic infiltration (Figures 4(a) and 4(b)) and portal vascular congestion (Figure 4(a)). Rat treated with $1000 \mathrm{mg} / \mathrm{kg} /$ day on the other hand also showed mild portal lymphocytic infiltration (Figure 4(b)).

3.7. Histopathology of Kidney of Experimental Model Treated with E. pulcherrima Extracts. The result of the histopathology of kidney of control group and rats treated with doses 10 , 
TABLE 5: Effect of the E. pulcherrima extract on the serum level of ALAT, ASAT, ALP, T protein, albumin, and bilirubin (liver function parameters) of rats.

\begin{tabular}{|c|c|c|c|c|}
\hline Liver function & Group A & Group B & Group C & Group D \\
\hline Parameters & $(1000 \mathrm{mg} / \mathrm{Kg})$ & $(100 \mathrm{mg} / \mathrm{Kg})$ & $(10 \mathrm{mg} / \mathrm{Kg})$ & (Control) \\
\hline Reference value & Mean \pm SE & Mean \pm SE & Mean \pm SE & Mean \pm SE \\
\hline $\begin{array}{l}\text { ALAT }(\mathrm{u} / \mathrm{L}) \\
\text { (up to } 22 \mathrm{UI})\end{array}$ & $29.00 \pm 1.48$ & $32.00 \pm 1.67$ & $26.00 \pm 2.41$ & $32.20 \pm 2.42$ \\
\hline $\begin{array}{l}\text { ASAT }(\mathrm{u} / \mathrm{L}) \\
\text { (up to } 218 \text { ) }\end{array}$ & $46.20 \pm 1.88$ & $39.80 \pm 4.39$ & $48.40 \pm 7.42$ & $49.80 \pm 3.64$ \\
\hline $\begin{array}{l}\operatorname{ALP}(u / L) \\
(60-170)\end{array}$ & $226.60 \pm 17.15$ & $220.20 \pm 7.52$ & $206.00 \pm 6.50$ & $207.00 \pm 5.33$ \\
\hline $\begin{array}{l}\text { T. Protein }(\mathrm{g} / \mathrm{L}) \\
(58-80)\end{array}$ & $80.00 \pm 0.71$ & $80.80 \pm 1.39$ & $81.60 \pm 0.75$ & $83.00 \pm 1.34$ \\
\hline $\begin{array}{l}\text { T. bilirubin }(\mu \mathrm{mol} / \mathrm{L}) \\
(1.7-17.1)\end{array}$ & $22.00 \pm 1.05$ & $21.00 \pm 0.71$ & $20.40 \pm 0.60$ & $21.40 \pm 0.40$ \\
\hline $\begin{array}{l}\text { C. bilirubin }(\mu \mathrm{mol} / \mathrm{L}) \\
(1.7-8.5)\end{array}$ & $12.00 \pm 0.63$ & $11.20 \pm 0.66$ & $10.80 \pm 0.58$ & $11.60 \pm 0.40$ \\
\hline $\begin{array}{l}\text { Albumin }(g / L) \\
(35-50 \mathrm{~g})\end{array}$ & $51.80 \pm 1.36$ & $51.80 \pm 1.07$ & $51.00 \pm 0.71$ & $55.80 \pm 2.31$ \\
\hline
\end{tabular}

Values are expressed as mean \pm SEM for $N=5$. Values are considered significant if $(P<0.05)$.

TABLE 6: The effect of E. pulcherrima extract on the relative organ weight of liver and kidney.

\begin{tabular}{lccccc}
\hline Organ & Ref. value & $\begin{array}{c}\text { Group A } \\
(1000 \mathrm{mg} / \mathrm{Kg}) \\
\text { Mean } \pm \text { SE }\end{array}$ & $\begin{array}{c}\text { Group B } \\
(100 \mathrm{mg} / \mathrm{Kg}) \\
\text { Mean } \pm \text { SE }\end{array}$ & $\begin{array}{c}\text { Group C } \\
(10 \mathrm{mg} / \mathrm{Kg})\end{array}$ & $\begin{array}{c}\text { Group D } \\
(\mathrm{Control})\end{array}$ \\
\hline Liver & 0.82 & $0.0469 \pm 0.0058$ & $0.0426 \pm 0.0031$ & $0.0395 \pm 0.0019$ & $0.0438 \pm 0.0043$ \\
Kidney & 0.76 & $0.0043 \pm 0.0004$ & $0.0046 \pm 0.0002$ & $0.0046 \pm 0.0003$ & $0.0046 \pm 0.0004$ \\
\hline
\end{tabular}

Values are expressed as mean \pm SEM for $N=5$. Values are considered Significant if $(P<0.05)$.

TABLE 7: The descriptive analyses of the total and differential leucocytes counts.

\begin{tabular}{|c|c|c|c|c|}
\hline \multirow[t]{2}{*}{ Liver parameters } & $\begin{array}{l}\text { Group A } \\
(10 \mathrm{mg} / \mathrm{Kg})\end{array}$ & $\begin{array}{c}\text { Group B } \\
(100 \mathrm{mg} / \mathrm{Kg})\end{array}$ & $\begin{array}{c}\text { Group C } \\
(1000 \mathrm{mg} / \mathrm{Kg})\end{array}$ & $\begin{array}{l}\text { Group D } \\
\text { (Control) }\end{array}$ \\
\hline & Mean \pm SE & Mean \pm SE & Mean \pm SE & Mean \pm SE \\
\hline PCV (\%) & $46.33 \pm 0.88$ & $4.00 \pm 2.31$ & $45.67 \pm 1.20$ & $41.00 \pm 4.04$ \\
\hline $\mathrm{Hb}(\mathrm{g} / \mathrm{dL})$ & $15.43 \pm 0.30$ & $15.63 \pm 0.78$ & $15.20 \pm 0.42$ & $13.63 \pm 1.34$ \\
\hline T. Prot. (g/dL) & $4.87 \pm 0.59$ & $5.60 \pm 0.31$ & $5.60 \pm 0.20$ & $5.20 \pm 0.31$ \\
\hline $\mathrm{WBC}\left(\times 10^{9} / \mathrm{L}\right)$ & $5.63 \pm 0.61$ & $5.27 \pm 1.51$ & $3.37 \pm 0.34$ & $2.70 \pm 0.65$ \\
\hline NEUT (\%) & $27.00 \pm 3.46$ & $36.00 \pm 0.58$ & $17.00 \pm 5.03$ & $26.67 \pm 6.49$ \\
\hline LYMPH (\%) & $72.67 \pm 3.48$ & $59.00 \pm 2.31$ & $81.33 \pm 5.36$ & $68.67 \pm 7.88$ \\
\hline $\mathrm{RBC}\left(\times 10^{6} / \mathrm{L}\right)$ & $7.70 \pm 0.15$ & $7.80 \pm 0.40$ & $7.60 \pm 0.21$ & $6.80 \pm 0.66$ \\
\hline
\end{tabular}

Values are expressed as mean \pm SEM for $N=5$. Values are considered significant if $(P<0.05)$.

$100 \mathrm{mg} / \mathrm{kg} /$ day showed a similar pattern with majority of group members showing mild renal tubular dilation (MRTD) (Figures 7(a) and 7(b)) while others showed normal histology (Figure 6). Remarkably majority of the members of the group treated with $1000 \mathrm{mg} / \mathrm{kg} /$ day showed normal histology (Figure 6). Only one of the member showed mild renal tubular dilation (Figure 7(a)). This implies that MRTD could possibly be remedied with the extract of E. pulcherrima at higher concentration.

\section{Discussion}

Literature had reported claims that natural plant products are relatively safe and could be used after they have undergone thorough toxicological evaluations using modern scientific methods and passed the test [18]. It is a documented fact that any drug used in treatment of any ailment is not totally free from harmful effects. Plant extracts are also not left out as they can only be beneficial after a careful measurement 


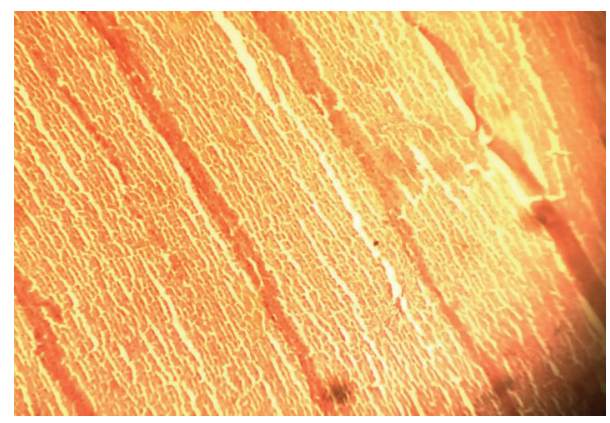

FIGURE 3: Micrograph of the liver of a control rat showing the central vein, sinusoid, portal triad, and hepatocytes $\times 400$.

of the pros and cons associated with their use. These can be achieved by initiation of toxicity assessment of the extract using experimental model. Indices such as $\mathrm{LD}_{50}$ and any effect on the organs of metabolism and homeostasis such as liver and kidney can be evaluated to ascertain the toxicity status of such plant extract. Advance toxicity studies such as subchronic study in animal model could also assist in predicting the potential toxic state of the plant extracts, from which possible interpolation of the response may be correlated with human and in addition may give an idea about the organ system involvement $[18,20]$. The results of this investigation showed that extract of E. pulcherrima whole plant has the percentage yield of $5.14 \%$, using methanol as the solvent of extraction. Characterization of the euphorbia extract to identify the potentially active compounds has been reported by Sharif et al., 2014 [21].

The acute toxicity study of the extract revealed that the $\mathrm{LD}_{50}$ value is $3807.89 \mathrm{mg} / \mathrm{kg}$ (Table 1 ) both orally and intraperitoneally which is within the standard range of 500$5000 \mathrm{mg} / \mathrm{kg}$ body weight. Hence, the methanol extract of $E$. pulcherrima can be described as practically nontoxic on the scale proposed by (Lorke, 1983) [13].

The result of this study indicates that the control and the treated groups with 10,100 , and $1000 \mathrm{mg} / \mathrm{kg}$ of the extract of the E. pulcherrima did not show significant change in the kidney and liver function parameters. Even though the result indicated elevation of the serum urea and creatinine levels above the normal reference values in both the control group and the group treated with $10 \mathrm{mg} / \mathrm{kg}$ of the extract with mean values $7.92 \pm 1.19$ and $7.86 \pm 1.14 \mathrm{mMol} / \mathrm{L}$ for urea (Table 2). The statistical analysis of the results showed a negative correlation between the concentration of the plant extract and the level of urea and creatinine (i.e., by implication when concentration increased, the levels of the parameters decreased). The changes cannot be directly linked to the toxicity effect of the extract, since the mean values of the creatinine and urea of the groups treated with higher concentration of the extracts were practically not influenced positively by the extract. However, these results possibly suggest the potential of the plant to be employed in the treatment of the diseases that are associated with elevation of serum level of creatinine and urea. However, this study suggests a further assessment of the nephron-protective potential of $E$. pulcherrima as indicated by the kidney histopathology result, which showed that the rats in control group and rats treated with doses 10 and $100 \mathrm{mg} / \mathrm{kg} /$ day showed a similar pattern with majority of group members showing mild renal tubular dilation (MRTD) (Figures 7(a) and 7(b)) while others showed normal histology (Figure 6). However, the group treated with $1000 \mathrm{mg} / \mathrm{kg} /$ day indicated that the majority of the group members showed normal histology (Figure 6) and only one member showed mild renal tubular dilation (Figure $7(\mathrm{a})$ ).

The result of the liver function test as indices in screening the toxicity activity of E. pulcherrima methanol extract (Table 5) revealed the elevation of ALAT, ALP, T protein albumin, and bilirubin above the normal reference values, while ASAT level was within the normal reference values (Table 6). However, the statistical analysis of ALAT, ASAT, ALP, T protein albumin, and bilirubin in all cases showed $P>0.05$, that is, no significant difference in the average values of the parameters. The extract did not alter ALT, ASAT ALP, $T$ protein albumin, and bilirubin concentration in the serum of the treated rats significantly. This is an indication that the extract has no aggressive effects on the metabolism and the excretion of the tested metabolites/enzymes in rats.

The nonsignificant alteration in ALT and ASAT sera in the experimental models indicated non-hepatotoxic potential of the plant E. pulcherrima. ALT and ASAT are usually present in high concentration in the liver, where their main function is to take part in transamination activities. However, further research to consider the possible hepatoprotective effect of the plant extract is recommended. The presence of these enzymes in high level in liver could be associated with liver necrosis and other conditions that promote abnormal liver cell membrane permeability [22]. Moreover, cytoplasmic enzymes are only found in high concentration in mild liver injury, while severe liver damage results in the release of both mitochondrial enzymes and the cytoplasmic enzymes [22]. The results of the liver histopathology however indicated some element of the extract's mild negative effect on the hepatic cells. The result showed that the control group and the group treated with $10 \mathrm{mg} / \mathrm{kg} /$ day of the extract showed normal histology of liver (Figure 3 ). However, one rat treated with $100 \mathrm{mg} / \mathrm{kg} /$ day showed mild portal lymphocytic infiltration (Figure 5) and other two rats showed portal vascular congestion (Figure 4(a)) in the group. A rat treated with $1000 \mathrm{mg} / \mathrm{kg} /$ day on the other hand showed portal vascular congestion (Figure 4(b)) and all other members of the group showed normal histology. It is pertinent to note that out of the 15 animals treated with the plant only 4 animals indicated some elements of negative effect. This is possibly not as a result of the effect of the extract, as the effect is expected to be more pronounced in the animal group treated with highest concentration. It is however recommended that further work should be designed to rule out such observed effect.

\section{Conclusion}

From the results, it can be concluded that E. pulcherrima does not pose any challenge to the physiological state of both liver and kidney even when consumed at higher concentrations 


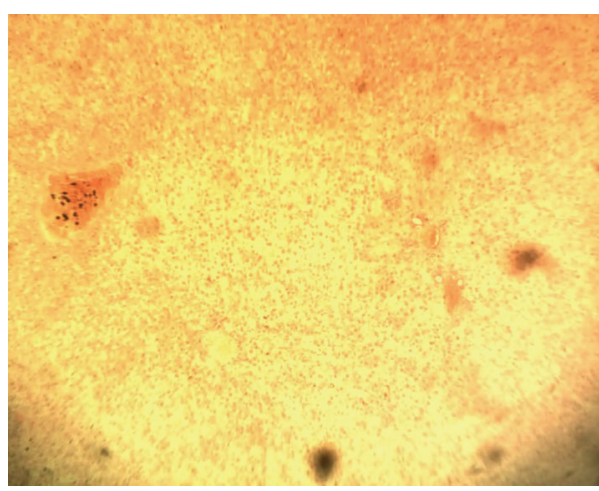

(a)

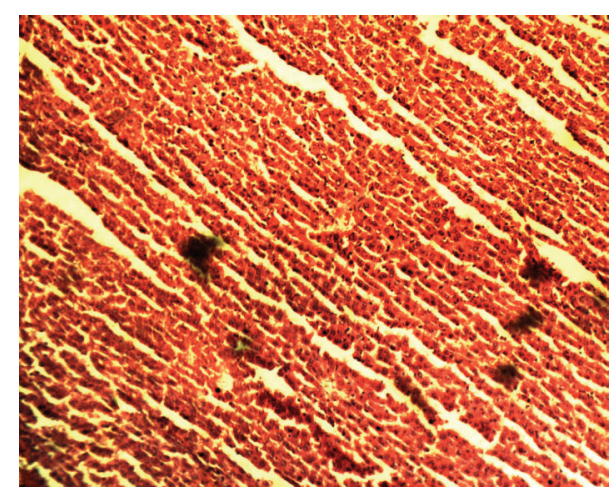

(b)

Figure 4: (a) and (b) micrograph of the liver of a rat treated with 100 and $1000 \mathrm{mg} / \mathrm{kg}$ body weight of the extract showing portal vascular congestion and mild portal lymphocytic infiltration, respectively, $\times 400$ magnification.

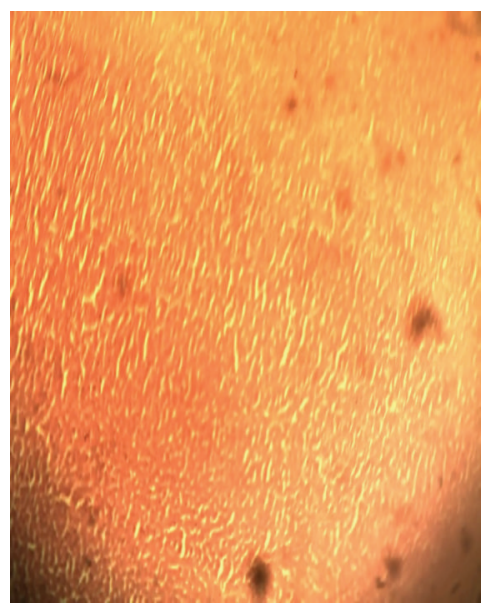

(a)

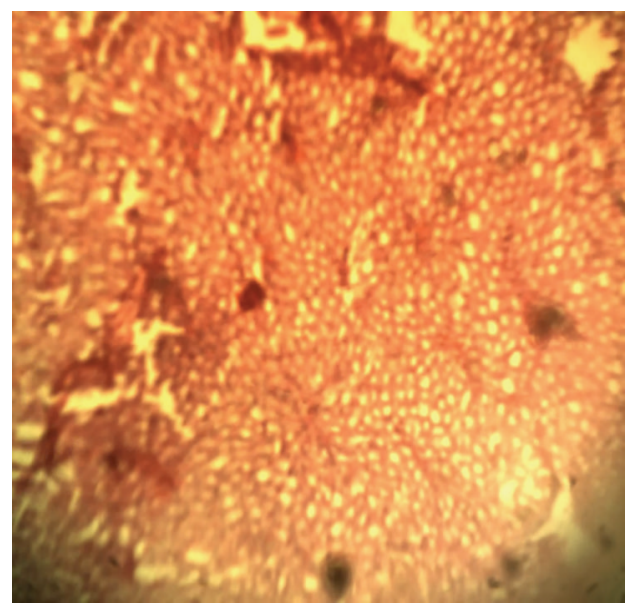

(b)

FIGURE 5: (a) and (b) micrograph of liver from group of rats administered $100 \mathrm{mg} / \mathrm{kg}$ body weight of extracts showing mild portal lymphocytic infiltration $\times 400$.

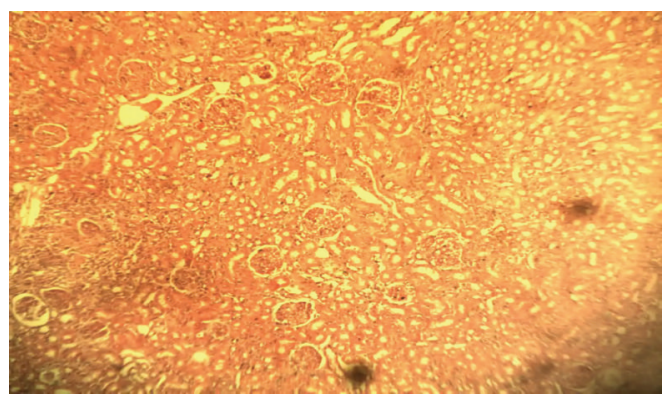

(a)

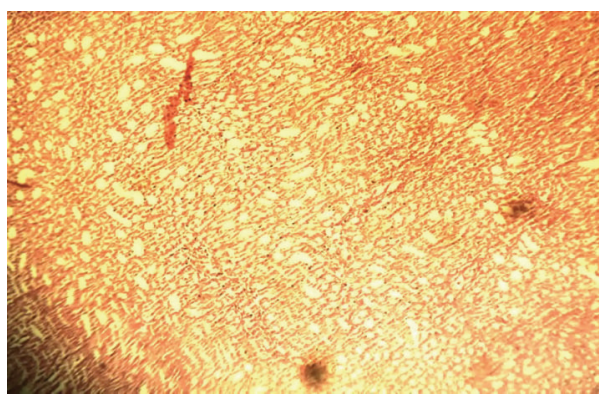

(b)

FIGURE 6: (a) and (b) micrograph of the kidney sections of control rat showing normal histology $\times 400$.

over a long period. The effect is therefore not concentration dependent.

These scientific evidences showed that the extract under study possesses some chemical compounds and pharmacological properties similar to the classes of drugs that do not have the potentials to induce any liver or kidney damage. However, some mild hepatic histological changes were observed among a few members of the groups treated with 100 and $1000 \mathrm{mg} / \mathrm{kg} / \mathrm{day}$ of the extract. Based on these findings, it is recommended that chronic toxicity studies be 


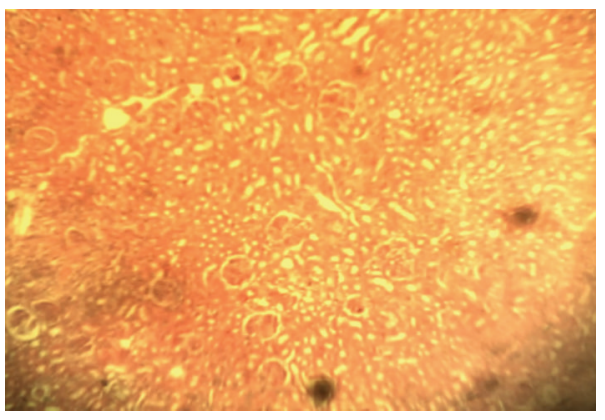

(a)

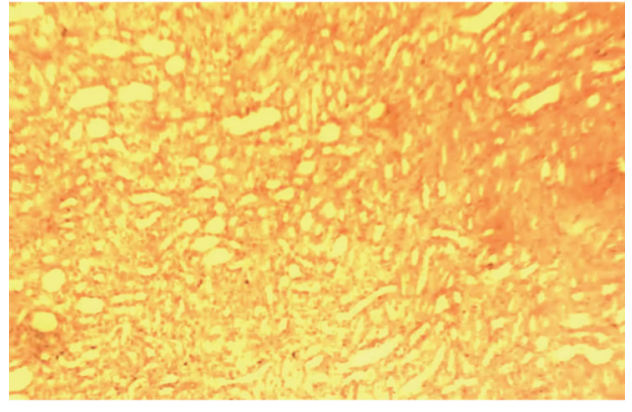

(b)

FIGURE 7: (a) and (b) kidney sections of rats of all groups treated and not treated, showing mild tubular dilation (MRTD) of the renal tubules $\times 400$.

designed to specifically rule out such observed mild hepatic histological changes and the hepatoprotective and nephronprotective potentials of the plant extract.

\section{Conflict of Interests}

The authors declare that there is no conflict of interests regarding the publication of this paper.

\section{References}

[1] M. M. Cowan, "Plant products as antimicrobial agents," Clinical Microbiology Reviews, vol. 12, no. 4, pp. 564-582, 1999.

[2] A. A. Adedapo, M. O. Abatan, and O. O. Olorunsogo, "Toxic effects of some plants in the genus Euphorbia on haematological and biochemical parameters of rats," Veterinarski Arhiv, vol. 74, no. 1, pp. 53-62, 2004.

[3] M. R. Heidari, A. Mandgary, and M. Enayati, "Antinociceptive effects and toxicity of Fumaria parviflora lam. in mice and rats," Daru, vol. 12, no. 4, pp. 136-140, 2004.

[4] A. A. Adeneye, O. P. Ajagbonna, T. I. Adeleke, and S. O. Bello, "Preliminary toxicity and phytochemical studies of the stem bark aqueous extract of Musanga cecropioides in rats," Journal of Ethnopharmacology, vol. 105, no. 3, pp. 374-379, 2006.

[5] E. U. Etuk, B. M. Agaie, P. A. Onyeyili, and C. U. Ottah, "Toxicological studies of aqueous stem bark extract of Boswellia dalzielii in albino rats," Indian Journal of Pharmacology, vol. 38, no. 5, pp. 359-360, 2006.

[6] K. Kalimuthu, S. Vijayakumar, and R. Senthilkumar, "Antimicrobial activity of the biodiesel plant, Jatropha curcas L.," International Journal of Pharma and BioSciences, vol. 1, no. 3, pp. 1-5, 2010.

[7] F. O. Ekundayo, C. A. Adeboye, and E. A. Ekundayo, "Antimicrobial activities and phytochemical screening of pignut (Jatrophas curcas Linn.) on some pathogenic bacteria," Journal of Medicinal Plants Research, vol. 5, no. 7, pp. 1261-1264, 2011.

[8] N. A. Siddique, M. Meyerb, A. K. Najni, and M. Akram, "Evaluation of antioxidants activity, quantitative estimation of phenols and flavonoids in different parts of Aegle armelo," African Journal of Plant Science, vol. 4, pp. 1-5, 2010.

[9] G. Bussel, "Get ready for Holiday flowers," Southern Living, vol. 44, no. 12, p. 88, 2009.

[10] J. Duke, "Euphoria pulcherrima wild," in CRC Handbook of Medicinal Herbs, pp. 163-164, CRC Press, Boca Raton, Fla, USA, 1989.
[11] W. Marina, How Dangerous are Euphorbias? (Family Euphorbiaceae), 2014, http://www.theamateursdigest.com/epoisons.htm.

[12] A. I. Yakubu and M. D. Mukhtar, "Phytochemical in vitro antimicrobial activity of some phytochemical fractions of Euphorbia pulcherrima L.(Poinsettia)," Journal of Medicinal Plants Research, vol. 5, pp. 2470-2475, 2011.

[13] D. Lorke, "A new approach to practical acute toxicity testing," Archives of Toxicology, vol. 54, no. 4, pp. 275-287, 1983.

[14] A. Sofowora, Medicinal Plants and Traditional Medicine in Africa, Spectrum Books Limited, Ibadan, Nigeria, 1993.

[15] F. J. Baker, R. E. Silverton, and C. J. Pallister, Baker and Silverton's Introduction to Medical Laboratory Technology, ButterworthHeinemann, Oxford, UK, 7th edition, 1998.

[16] O. I. Oyewole, O. O. Oyedara, B. F. Olabiyi, and T. S. Fasanya, "Phytochemical, antimicrobial and toxicity studies of Phyllanthus amarus whole plant extract," International Journal of Bioassays, vol. 2, no. 3, pp. 519-523, 2013.

[17] M. S. Oh, "Evaluation of renal function, water, electrolytes and acid-base balance," in Henry's Clinical Diagnosis and Management by Laboratory Methods, R. A. McPherson and M. R. Pincus, Eds., pp. 187-224, Elsevier Saunders, Philadelphia, Pa, USA, 21st edition, 2006.

[18] S. O. Aniagu, F. C. Nwinyi, D. D. Akumka et al., "Toxicity studies in rats fed nature cure bitters," African Journal of Biotechnology, vol. 4, no. 1, pp. 72-78, 2005.

[19] F. C. Chidume, H. O. Kwanashie, J. O. Adekeye, C. Wambebe, L. É. Odama, and K. S. Gamaniel, "Evaluation of the methanolic extract of Cassia tora leaves for immunomodulatory and antimicrobial activities," Journal of Phytomedicine and Therapeutics, vol. 7, no. 1-2, pp. 46-55, 2002.

[20] R. S. Cotran, S. Kumar V, N. Fausto, F. Nelso, S. L. Robbins, and A. K. Abbas, Robbins and Cotran Pathologic Basis of Disease, Elsevier Saunders, St. Louis, Mo, USA, 7th edition, 2005.

[21] H. B. Sharif, M. D. Mukhtar, Y. Mustapha, and A. O. Lawal, "Preliminary investigation of bioactive compounds and bioautographic studies of whole plant extract of Euphorbia pulcherrima on Escherichia coli, Staphylococcus aureus, Salmonella typhi, and Pseudomonas aeruginosa," Advances in Pharmaceutics, vol. 2015, Article ID 485469, 14 pages, 2015.

[22] J. S. Cameron and R. Greger, "Renal function and testing of function," in Oxford Textbook of Clinical Nephrology, A. M. Davison, J. S. Cameron, J. P. Grunfeld, D. N. S. Kerr, E. Rits, and G. C. Winearl, Eds., pp. 36-39, Oxford University Press, 1998. 

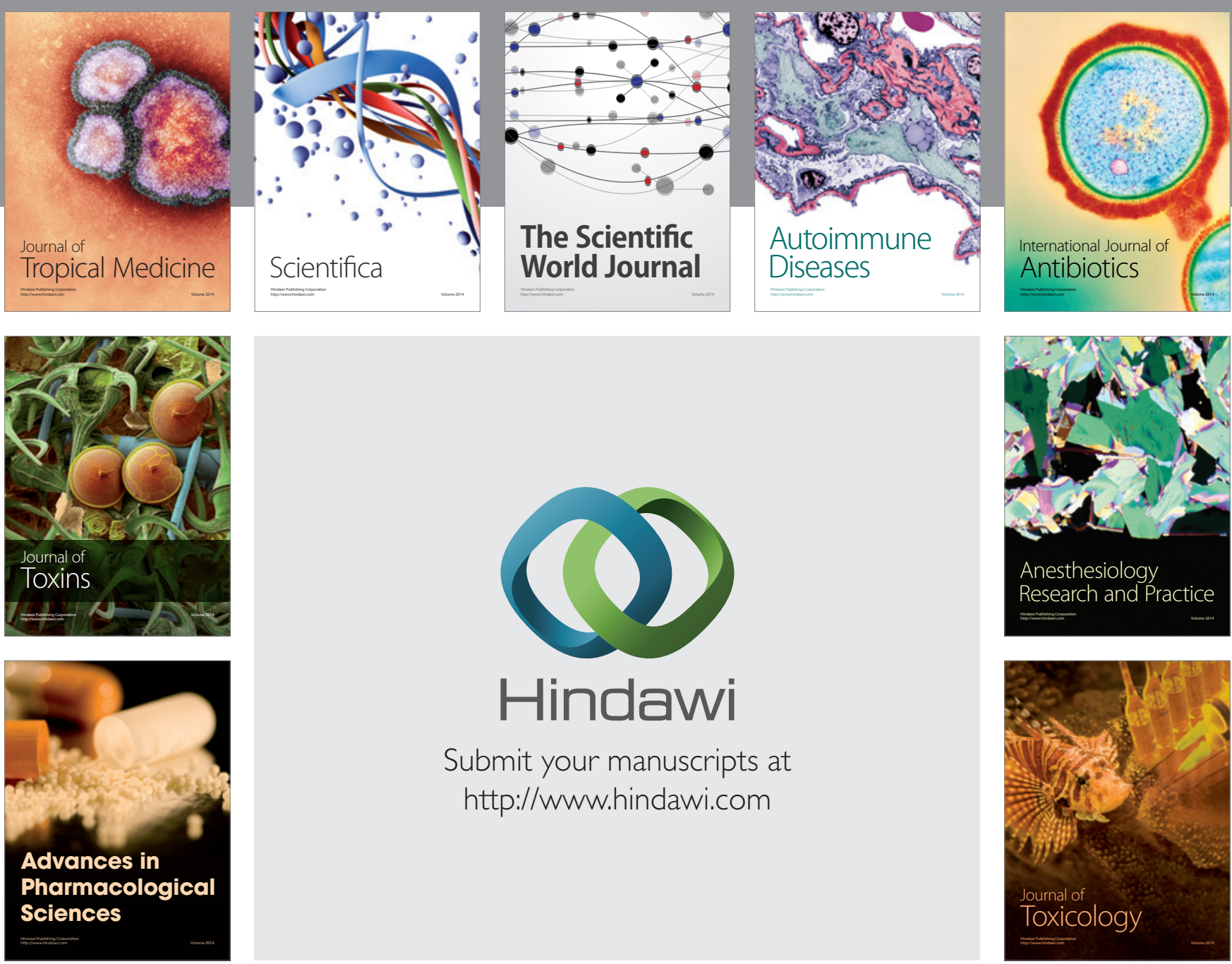

\section{Hindawi}

Submit your manuscripts at

http://www.hindawi.com
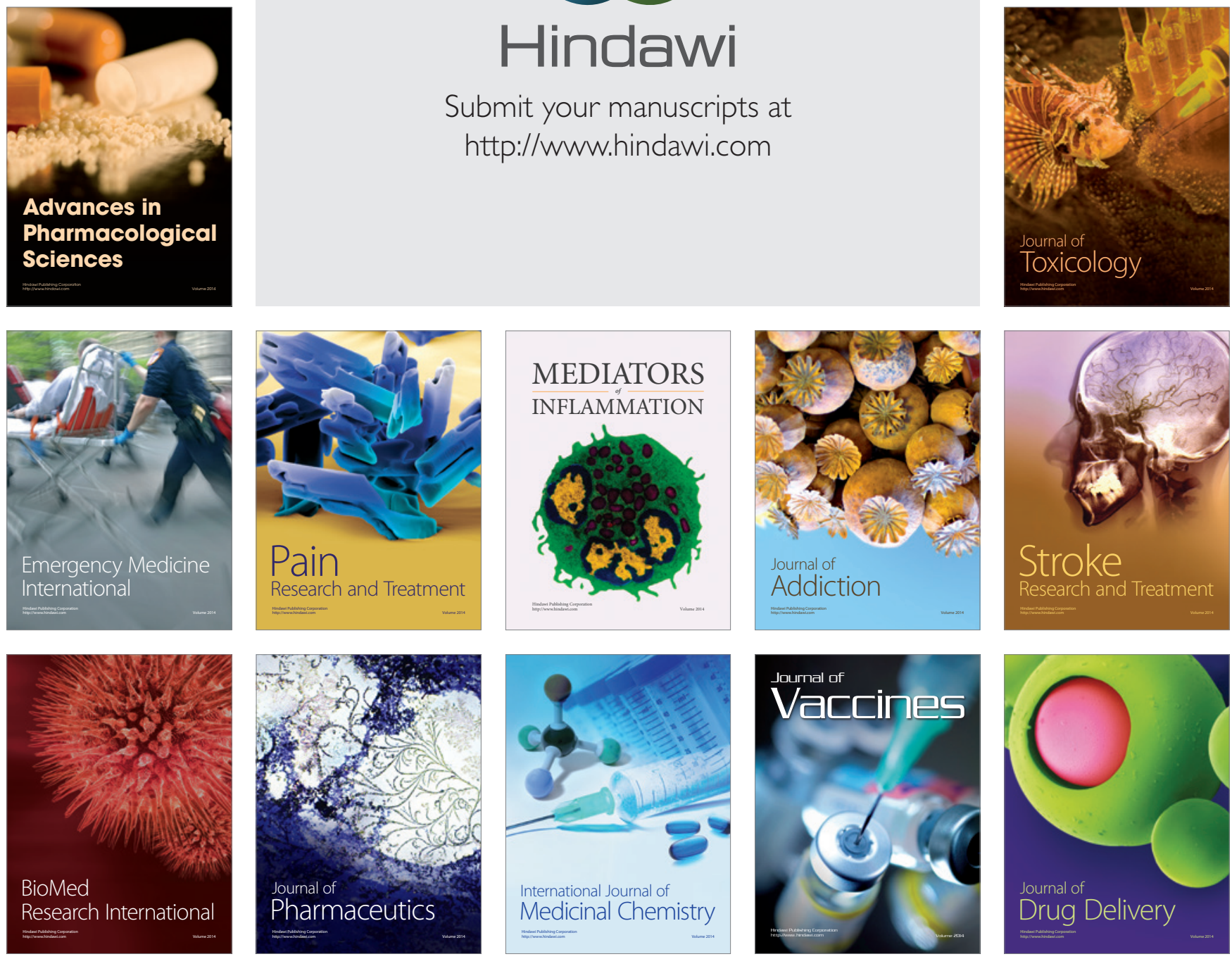